\title{
GMR
}

\section{Cleaning cassava genotypes infected with cassava frogskin disease via in vitro shoot tip culture}

\author{
M.J.S. Carvalho ${ }^{1}$, E.J. Oliveira ${ }^{1,2}$, A.S. Souza ${ }^{1}$, J.S. Pereira ${ }^{2}$, \\ M.S.A.S. Diamantino ${ }^{1}$ and S.A.S. Oliveira ${ }^{1}$ \\ ${ }^{1}$ Núcleo de Recursos Genéticos e Desenvolvimento de Variedades, \\ Embrapa Mandioca e Fruticultura, Cruz das Almas, BA, Brasil \\ ${ }^{2}$ Centro de Ciências Agrárias Ambientais e Biológicas, \\ Universidade Federal do Recôncavo da Bahia, Cruz das Almas, BA, Brasil \\ Corresponding author: E.J. Oliveira \\ E-mail: eder.oliveira@embrapa.br \\ Genet. Mol. Res. 16 (2): gmr16029556 \\ Received November 29, 2016 \\ Accepted April 27, 2017 \\ Published May 31, 2017 \\ DOI http://dx.doi.org/10.4238/gmr16029556
}

Copyright (C) 2017 The Authors. This is an open-access article distributed under the terms of the Creative Commons Attribution ShareAlike (CC BY-SA) 4.0 License.

ABSTRACT. This study aimed to develop a methodology for
eliminating cassava frogskin disease (CFSD) from in vitro shoot tip
culture by associating thermotherapy and tetracycline. Cuttings from
different accessions (BGM0232, BGM0315, BGM0464, BGM584,
BGM0841, and BGM1342), infected with CFSD according to visual
inspection of the disease symptoms, were used for cleaning. To verify
the absence of other diseases, the plants were indexed for Cassava
common mosaic virus - CsCMV (by ELISA) and Cassava vein mosaic
virus - CsVMV (by polymerase chain reaction, PCR), proving that
the accessions were free of these viruses, except for BGM0315 and
BGM0464, which were infected with CsVMV. Subsequently, the
cuttings were submitted to different tetracycline concentrations for 3
min, and then subjected to thermotherapy under different temperatures
$\left(35^{\circ}, 38^{\circ}, 40^{\circ}, 45^{\circ}\right.$, and $55^{\circ} \mathrm{C}$ ). Shoots of $2 \mathrm{~cm}$ were harvested, and
their surfaces were sterilized in a laminar flow chamber. Subsequently,
the shoot tips of different sizes were removed (0.2, $0.4,0.5$, and 1.0

Genetics and Molecular Research 16 (2): gmr16029556 
$\mathrm{mm}$ ) for inoculation in a culture medium with tetracycline at the same concentrations in which the cuttings were dipped. After 60 days of cultivation, the explants were transferred to a multiplication medium without antibiotics. Thirty days after the transfer, the viability of the regenerated plants was evaluated, which were then acclimatized for 70 days in a greenhouse and transferred to the field. After 7 months, a visual analysis of the symptomatic roots and a PCR analysis were held to prove the elimination of CFSD and CsVMV from the accessions infected with these viruses (BGM0315 and BGM0464), respectively. Most of the treatments resulted in 100\% cleaning of CFSD-infected plants. From accessions that were also infected with CsVMV, only $2 \%$ of the plants remained infected, also demonstrating the cleaning efficiency of this protocol for this disease.

Key words: Manihot esculenta Crantz; Cassava frogskin disease; Thermotherapy; Tetracycline

\section{INTRODUCTION}

Cassava (Manihot esculenta Crantz), one of the main crops for human and animal consumption, has great economic and social importance for many countries. Additionally, some traits, such as its drought tolerance, make this species appropriate for cultivation in different regions, with wide adaptation to different climate and soil conditions (Lenis et al., 2006; Foloni et al., 2010) and tolerance to pests and diseases (Venturini et al., 2015). In addition, Oliveira et al. (2015) emphasize its relatively stable productivity in different environments and flexibility at harvest. However, globally, the main components related to impairment of cassava production are soil and climatic growing conditions and the quality of cuttings, which cause unevenness in plant development and result in production losses (Mattos et al., 2006). Other biotic constrains, such as mites, insects, and many diseases as root rot, cassava bacterial blight, Cassava vein mosaic virus (CsVMV), Cassava common mosaic virus (CsCMV), and cassava frogskin disease (CFSD), have caused severe restrictions on cassava production in Latin America (Calvert and Thresh, 2002; López et al., 2006; Carvajal-Yepes et al., 2014; Souza et al., 2014). The CFSD directly affects the starch, root quality and thus crop yield of cassava (Calvert and Thresh, 2002; Alvarez et al., 2009).

The etiology of CFSD is complex because some authors attribute the disease to different species off viruses, such as Cassava frogskin-associated virus (CsFSaV; Reoviridae/ Oryzavirus), Cassava torrado-like virus (CsTLV; Secoviridae/Torradovirus), Cassava new alphaflexivirus (CsNAV; Alphaflexiviridae/Potexvirus), and Cassava polero-like virus (CsPLV; Luteoviridae/Polerovirus) (Carvajal-Yepes et al., 2014), and also with phytoplasma belongings to the 16SrIII-L (Alvarez et al., 2009; Oliveira et al., 2014) and 16SrIII-A (Souza et al., 2014) subgroups.

Plants infected with this disease usually have no symptoms on the aerial part; while the tuberous root exhibited a woody appearance, thickened cork-like peel with opaque aspect, and coalescent lip-like slits in a honeycomb pattern; whereas severe affected plants do not show formation of tuberous roots, due to the abscence of starch accumulations (Calvert and Thresh, 2002; Alvarez et al., 2009; Carvajal-Yepes et al., 2014). Calvert and Thresh (2002) pointed out

Genetics and Molecular Research 16 (2): gmr16029556 
that, in some situations, certain genotypes of cassava mosaic symptoms can develop on leaves and stems near the ground can be slightly swollen.

Controlling CFSD involves the removal of diseased plants, the sanitization of tools with sodium hypochlorite, the use of healthy cuttings, the establishment phytosanitary quarantine and the adoption of measures to prevent its spread, especially to areas free of the disease (Calvert and Thresh, 2002; Alvarez et al., 2009). As cassava is a vegetatively propagated plant, the accumulation of phytoplasma and/or virus in cuttings is recurrent, resulting in losses in root yield that can reach 90\% (Alvarez et al., 2009) and, in extreme cases, $100 \%$ (Oliveira EJ, unpublished results). An important strategy to control CFSD in infected plants is to clean these materials via meristem culture, thermotherapy, antibiotics, cryotherapy, and micrografting (Milošević et al., 2012). According to Panattoni et al. (2013), thermotherapy has been the most commonly applied technique in cleaning protocols for plants infected by systemic disease induced by viruses belonging to 13 families since 1991, being the use of treatments in association the most reliable strategy.

According to Menezes Júnior (2011), thermotherapy associated with in vitro cultivation helps reduce systemic pathogens, such as viruses. The cultivation of the infected plants at high temperatures significantly reduces virus replication by interrupting nucleic acid synthesis, and the same occurs with other systemic pathogens, such as phytoplasma. However, the optimal temperature for inhibiting this replication is highly variable in different pathogens, although thermotherapy combined with meristem culture may improve the efficiency of pathogen elimination (Milošević et al., 2012). Moreover, chemotherapy with the use of ribavirin, ditiouracil, tetracycline, cefotaxime, and erythromycin in association with the cultivation of meristems and apex shoots and in combination with thermotherapy has also been promising for the elimination of pathogens (Nascimento et al., 2003; Panattoni et al., 2007, 2013).

To Milošević et al. (2012), the pathogen distribution in apexes may vary depending on the host-pathogen interaction in regard to infection degree making it necessary to investigate the appropriate explant size to completely eliminate the pathogen and not interfere with the plant regeneration. There are reports in the literature on the use of meristem or shoot tips that are 0.2 to $0.7 \mathrm{~mm}$ long for pathogen eradication (Singh et al., 2007; Panattoni et al., 2013; Mwangangi et al., 2014).

According to Wang and Valkonen (2008), phytoplasma restriction in young tissues occurs because the phloem vessel elements are developing and therefore do not allow the passage or movement of such pathogens. Therefore, the in vitro culture of apexes and meristems has been used for cleaning infected plants with virus, bacteria, and phytoplasmas (Singh et al., 2007; Banerjee et al., 2010). Moreover, these authors reported that the size of apexes can influence this cleaning process, as phytoplasma was detected in sweet potato apexes of 1.0 and $1.5 \mathrm{~mm}$, but not in $0.5-\mathrm{mm}$ apexes. In meristem cultivation, another strategy for virus and phytoplasma control is cleaning plants with the use of antiviral substances and antibiotics, respectively. According to Panattoni et al. (2013), viral chemotherapy is based on the assumption that the nucleic acid synthesis of the virus may be inhibited by antiviral molecules. The success of explant in vitro cultures in culture medium with antiviral substances and antibiotics has been reported in several papers (Gribaudo et al., 2007; Singh et al., 2007; Mwangangi et al., 2014).

Milošević et al. (2012) emphasize that virus elimination is most effective when different techniques (meristem culture, thermotherapy, cryotherapy, and chemotherapy) are used jointly. Therefore, a combination of cleaning techniques may constitute an efficient alternative

Genetics and Molecular Research 16 (2): gmr16029556 
for the disposal of CFSD-infected cassava plants, since the etiology of this disease has not been fully confirmed. Hence, in vitro culture of shoot tips, associated with thermotherapy and chemotherapy, may be an effective strategy in eliminating viruses or phytoplasma in cassava plants infected with CFSD, which this study focused on. In other studies, the addition of cleaning techniques has shown promising results for virus and phytoplasma elimination (Senula et al., 2000; Chalak et al., 2005; Mwangangi et al., 2014).

Considering the lack of reports on CFSD-resistant cultivars and the difficulty in recognizing the symptoms of infected plants before harvest, as well as the significant reduction in tuberous root productivity and quality, it is necessary to develop cleaning strategies for currently infected cultivars. The objective of this study was to develop a frogskin elimination methodology based on cultivating in vitro shoot tips of infected cassava plants associated with thermotherapy and the use of tetracycline.

\section{MATERIAL AND METHODS}

\section{Plant material}

Cuttings from CFSD-infected plants of accessions 'Cidade Rica' (BGM0232), 'Riqueza II' (BGM0584), 'Mandioca Lagoa' (BGM1342), 'CM-425/7' (BGM0315), 'Sabará' (BGM0464), and 'Sauma' (BGM0841) that originated from the Cassava Active Germplasm Bank (BAG-Cassava) of Embrapa Mandioca e Fruticultura were used for this analysis. To ensure that these mother plants had no other disease, indexation was carried out using ELISA and polymerase chain reaction (PCR) for the Cassava common mosaic virus - CsCMV (Mowat and Dawson, 1987) - and Cassava vein mosaic virus - CsVMV (Calvert et al., 1995) respectively. The diagnosis showed that all accessions were free of CsCMV, but the BGM0315 and BGM0464 were infected with CsVMV.

\section{Treatments used in thermotherapy}

The cuttings taken from CFSD- and CsVMV-infected plants were germinated in plastic pots containing the commercial substrate (Vivatto, Technes Agrícola Ltda.) and subjected to the thermotherapy process using climate chambers with the following temperatures:

1) $55^{\circ} \pm 1^{\circ} \mathrm{C}$ during the day and $38^{\circ} \pm 1^{\circ} \mathrm{C}$ overnight; 2) $45^{\circ} \pm 1^{\circ} \mathrm{C}$ during the day and $35^{\circ} \pm 1^{\circ} \mathrm{C}$ overnight; 3 ) $40^{\circ} \pm 1^{\circ} \mathrm{C}$ during the day and $32^{\circ} \pm 1^{\circ} \mathrm{C}$ overnight; 4$) 38^{\circ} \pm 1{ }^{\circ} \mathrm{C}$ during the day and $32^{\circ} \pm 1^{\circ} \mathrm{C}$ overnight, with two $50^{\circ} \mathrm{C}$ peaks for $1 \mathrm{~h}$ (a peak early in the morning and another in the early afternoon); 5) $38^{\circ} \pm 1^{\circ} \mathrm{C}$ during the day and $32 \pm 1{ }^{\circ} \mathrm{C}$ overnight, and the cuttings were subjected to a pretreatment in water at $55^{\circ} \mathrm{C}$ for $10 \mathrm{~min}$ ); and 6) $35^{\circ} \pm 1^{\circ} \mathrm{C}$ throughout the time. to 4 weeks.

The photoperiod used in the acclimatized chambers was 16-h light for a period of 3

\section{Antibiotic treatments}

Initially, some preliminary tests were conducted to adjust tetracycline concentrations to prevent phytotoxic effects on the development of cassava plants:

- First test: three cassava accessions ['Cidade Rica' (BGM0232), 'Riqueza II'

Genetics and Molecular Research 16 (2): gmr16029556 
(BGM0584), and 'Mandioca Lagoa' (BGM1342)], three shoot tip sizes $(0.2,0.5$, and $1.0 \mathrm{~mm})$ and three tetracycline concentrations $(0,100$, and $400 \mathrm{mg} / \mathrm{L})$.

- Second test: three cassava accessions (BGM0232, BGM0584, and BGM1342), two microcutting sizes $(5$ and $10 \mathrm{~mm})$ and three tetracycline concentrations $(0,100$, and $400 \mathrm{mg} / \mathrm{L})$.

- Third test: three cassava accessions (BGM0232, BGM0584, and BGM01342) and seven tetracycline concentrations $(0,1.25,2.5,5,10,20$, and $40 \mathrm{mg} / \mathrm{L})$, using a shoot tip of $0.2 \mathrm{~mm}$.

- Fourth test: three cassava accessions ['CM-425/7'(BGM0315), 'Sabará'(BGM0464), and 'Sauma' (BGM0841)], two shoot tip sizes $(0.2$ and $0.4 \mathrm{~mm})$ and four tetracycline concentrations $(0,5,10$, and $15 \mathrm{mg} / \mathrm{L})$.

In all of the experiments, a completely randomized factorial design with 15 to 30 repetitions per treatment was used.

\section{Growing conditions}

After adjusting the temperature and antibiotic concentrations, cuttings from accessions BGM0315and BGM0464 were immersed in pots containing water with different tetracycline concentrations $(0,5,10$, and $15 \mathrm{mg} / \mathrm{L})$ for $3 \mathrm{~min}$, then transferred to polyethylene pots containing commercial substrate (Vivatto, Technes Agrícola Ltda.) and maintained at a constant temperature of $35^{\circ} \pm 1^{\circ} \mathrm{C}$.

The shots originating from the cuttings were kept in a climatized chamber and cut at approximately $2 \mathrm{~cm}$ in length, placed in the container with distilled water and then subjected to sanitization in a laminar flow chamber by immersion in 50\% ethanol for 3 min and sodium hypochlorite $(0.25 \%)$ for $3 \mathrm{~min}$ followed by triple washing in autoclaved distilled water.

After sanitization, the apexes of 0.2 and $0.4 \mathrm{~mm}$ were extracted. The explants were transferred to a growing cassava medium containing MS salts (Murashige and Skoog, 1962) supplemented with $1 \mathrm{mg} / \mathrm{L}$ thiamine, $100 \mathrm{mg} / \mathrm{L}$ inositol, $0.02 \mathrm{mg} / \mathrm{L}$ NAA (naphthaleneacetic acid), $0.04 \mathrm{mg} / \mathrm{L}$ BAP (benzylaminopurine), $0.05 \mathrm{mg} / \mathrm{L} \mathrm{GA}_{3}$ (gibberellic acid) and $20 \mathrm{~g} / \mathrm{L}$ sucrose; solidified with $2.4 \mathrm{~g} / \mathrm{L}$ Phytagel $^{\mathrm{TM}}$ (Sigma-Aldrich, Co.), with $\mathrm{pH}$ set to 5.8 and different concentrations of tetracycline $(0,5,10$, and $15 \mathrm{mg} / \mathrm{L})$; and then placed in a growth room with a temperature of $27^{\circ} \pm 1{ }^{\circ} \mathrm{C}$, a 16 -h photoperiod, and photon flow density of 30 $\mu \mathrm{mol} \cdot \mathrm{m}^{-2} \cdot \mathrm{s}^{-1}$ for 60 days.

After 60 days of establishing phase, the calluses formed on the basis of the apex were removed within a laminar flow chamber, and the explants transferred to test tubes containing the multiplication medium composed by the minerals from MS media supplemented with 0.01 $\mathrm{mg} / \mathrm{L}$ NAA, BAP and GA ${ }_{3}$, each, $20 \mathrm{~g} / \mathrm{L}$ sucrose and $2.4 \mathrm{~g} / \mathrm{L}^{\text {Phytagel }}{ }^{\mathrm{TM}}$ (Sigma-Aldrich, Co.) without tetracycline. The $\mathrm{pH}$ of the medium and the cultivation conditions were the same used during the establishment phase.

\section{Plant evaluation and acclimatization}

After 30 days of culture, the viability of the plants within each treatment was evaluated using the following parameters: plant height $(\mathrm{PH})$, in $\mathrm{cm}$; number of green leaves (NGL); number of microcuttings (NM) with about $1 \mathrm{~cm}$, and number of roots (NR). Acclimatization was carried out by washing the roots for removal of the culture medium; then, the plants were transferred to plastic bags containing a mixture of the autoclaved commercial substrate (Vivatto, Technes Agrícola Ltda.), organic soil and coconut coir (1:1:1). The plants were then

Genetics and Molecular Research 16 (2): gmr16029556 
watered and covered with plastic cups to avoid water loss. The plastic cups were removed when the plants reached about $8 \mathrm{~cm}$.

\section{Collecting leaf samples and field planting}

After 55 days of acclimatization in the greenhouse, plant leaf samples of each repetition of all treatments were packed in aluminum foil, identified, transferred to a cooler with ice and then stored at $-80^{\circ} \mathrm{C}$ in an ultrafreezer to perform indexing. After 70 days of acclimatization, the seedlings were planted in the field.

Planting was carried out in two randomized blocks; each experimental plot consisted of four to five plants, depending on the number of surviving plants on each treatment. Fertilization was carried out according to the soil analysis and hoeing for controlling weeds.

\section{Symptomatic analysis of plants in the field and molecular analysis to evaluate protocol effectiveness}

Seven months after planting in the field, plants were harvested to evaluate the CFSD symptoms and thus verify the efficiency of the protocol used for CFSD elimination through visual analysis for the presence or absence of disease symptoms in the roots (no formation of tuberous roots, fibrous roots, and cork epidermis and the presence of lip-like slits).

Besides visual analysis in the field, PCR was performed for detection of CsVMV (Calvert et al., 1995) in the plants derived from accessions BGM0315 and BGM0464 (originally infected with CFSD and CsVMV). For this, DNA was extracted from leaves collected from all plants of these genotypes from each cleaning treatment using the Doyle and Doyle (1987) protocol.

\section{Data analysis}

The data of explant viability in the treatments (accession, tetracycline concentrations, and shoot tip sizes) were subjected to analysis of variance. The averages of different treatments were compared by F and Tukey tests at 5\% probability. Since the objective was to define the best tetracycline concentration and not analyze the gap between them, polynomial regression models were not used. The parameters NGL, NM, and NR were converted to $\sqrt{x+0.5}$ in order to meet the assumptions of analysis of variance. All statistical analyses were performed using the Statistical Analysis System (SAS) software (SAS Institute, 2004).

\section{RESULTS AND DISCUSSION}

\section{Treatments used in thermotherapy}

All five treatments above $35^{\circ} \mathrm{C}$ temperatures adversely affect the sprouting, resulting in the death of cuttings and, therefore, the shoot development. Moreover, temperature treatment at $35^{\circ} \pm 1{ }^{\circ} \mathrm{C}$ did not cause the death of cuttings and allowed the proper shoot development and, therefore, the temperature used in all thermotherapy stages.

According Panattoni et al. (2013) temperatures most frequently used in studies published on thermotherapy from 1991 to 2010 were set between $35^{\circ}$ and $38^{\circ} \mathrm{C}$. Moreover,

Genetics and Molecular Research 16 (2): gmr16029556 
the growing meristem tips $(1 \mathrm{~mm})$ in cassava treated by thermotherapy at higher temperatures $\left(38^{\circ} \mathrm{C}\right.$ for 21 days) resulted in $68.8 \%$ of regenerated plants and were $84.4 \%$ free from Cassava brown streak virus (CBSV) (Mwangangi et al., 2014). The fact that these sprouts do not develop at higher temperatures may be due to increased sensitivity of the accessions used in these conditions. Moreover, even using lower temperatures $\left(35^{\circ} \mathrm{C}\right)$, there are reports of success in pathogens cleaning, such as potato clones whose increase in temperature decreased the survival rate of the explants, and $35^{\circ} \pm 1{ }^{\circ} \mathrm{C}$ gave the lowest survival percentage of meristems (20.47\%), but a higher rate of virus-free plants (43.79\%) (Ali et al., 2013). Another example, from a garlic culture, showed that treatment at $55^{\circ} \mathrm{C}$ for 5 min resulted in $50 \%$ bulbil survival, without removing viruses, whereas bulbil treatment at $36^{\circ} \mathrm{C}$ for 40 days allowed complete survival of the meristems and high-rate virus-free plants (84\%) (Senula et al., 2000).

\section{Antibiotic treatments}

In the initial experiments with tetracycline concentrations of 0,100 , and $400 \mathrm{mg} / \mathrm{L}, 0.2$ to $1.0 \mathrm{~mm}$ stem apices were used in the first test and 5- and $10-\mathrm{mm}$ microcuttings were used in the second test. In all these experiments, there was phytotoxicity and no plant regeneration in the doses used, even with a 50times increase in the explants' size $(0.2$ to $10 \mathrm{~mm})$. Therefore, the initial doses used were very high to start the in vitro cleaning process of accessions infected with CFSD. Using lower tetracycline concentrations (between 0 and $40 \mathrm{mg} / \mathrm{L}$ ), the third test showed higher viability and regeneration capacity of smaller explants $(0.2 \mathrm{~mm})$ to $10 \mathrm{mg} / \mathrm{L}$ tetracycline. However, from $20 \mathrm{mg} / \mathrm{L}$ there was lower development and death of explants, and the concentration of $40 \mathrm{mg} / \mathrm{L}$ resulted in the death of all apexes. Other studies have also demonstrated the toxicity symptoms caused by antibiotics in explants from different plant species. In potato in vitro culture, Pereira and Fortes (2003) reported severe phytotoxic effects on the growth and explant multiplication rate as a function of increasing concentrations $(0$, $32,64,128,256,512$, and $1024 \mathrm{mg} / \mathrm{L}$ ) of chloramphenicol, streptomycin, and tetracycline in the culture medium. In the study of Chalak et al. (2005), no plant was regenerated from 1 -cm microcuttings subjected to treatments with 50,100 , and $150 \mu \mathrm{g} / \mathrm{mL}$ oxytetracycline for phytoplasma cleaning (Candidatus Phytoplasma phoenicium) in almond tree varieties. Gribaudo et al. (2007) also observed phytotoxic effects in vine explants using oxytetracycline and showed that auxiliary buds were greatly affected when grown in a culture medium with $100 \mathrm{mg} / \mathrm{L}$ oxytetracycline.

Observations made during the first three preliminary tests with tetracycline were decisive for concentrations that allow plant regeneration to be evaluated for the CFSD elimination. Therefore, considering the high phytotoxicity observed in tetracycline dosages above $20 \mathrm{mg} / \mathrm{L}$, a fourth experiment was carried out at the concentrations of $0,5,10$, and 15 $\mathrm{mg} / \mathrm{L}$. With this reduction in the tetracycline dose, a better development of explants occurs, making it possible to assess the behavior of cassava accessions in vitro culture of shoot tips (Table 1).

To BGM0315, the higher PH values were found at tetracycline concentrations of 5 and $15 \mathrm{mg} / \mathrm{L}$, using 0.4 and $0.2 \mathrm{~mm}$ apical stems, respectively. For the accession BGM0464, no difference was found in PH between tetracycline concentrations and shoot tip sizes. Although there was no difference between the tetracycline concentrations of accession BGM0841, a difference was found between the shoot tip sizes in the absence and presence of $5 \mathrm{mg} / \mathrm{L}$ of the antibiotic, with higher values for the PH size of $0.2 \mathrm{~mm}$ (Figure 1).

Genetics and Molecular Research 16 (2): gmr16029556 
Table 1. Summary of analysis of variance for plant height $(\mathrm{PH})$ in $\mathrm{cm}$, number of green leaves (NGL), number of microcuttings (NM), and number of roots (NR) of cassava plants from two sizes of shoot tips (0.2 and $0.4 \mathrm{~mm}$ ) of accessions BGM0315, BGM0464, and BGM0841, cultivated in vitro at different tetracycline concentrations $(0,5,10$, and $15 \mathrm{mg} / \mathrm{L})$.

\begin{tabular}{l|c|c|c|c|c}
\hline Source of variation & \multirow{2}{*}{ d.f. } & \multicolumn{3}{|c}{ Mean square } \\
\cline { 3 - 6 } & & PH & NGL & NM & NR \\
\hline Accessions (AC) & 2 & $17.66^{*}$ & $13.80^{* *}$ & $0.94^{* *}$ & $0.29^{\text {ns }}$ \\
\hline Shoot tips (ST) & 1 & $0.97^{\text {ns }}$ & $3.28^{* *}$ & $0.36^{\text {ns }}$ & $2.43^{*}$ \\
\hline Tetracycline concentration (TC) & 3 & $14.57^{*}$ & $0.84^{\text {ns }}$ & $0.23^{\text {ns }}$ & $0.21^{\text {ns }}$ \\
\hline AC x ST & 2 & $19.12^{*}$ & $0.56^{\mathrm{ns}}$ & $1.02^{* *}$ & $1.20^{*}$ \\
\hline AC x TC & 6 & $16.40^{* *}$ & $2.15^{* *}$ & $0.13^{\text {ns }}$ & $0.85^{*}$ \\
\hline ST x TC & 3 & $8.17^{\text {ns }}$ & $1.95^{* *}$ & $0.15^{\text {ns }}$ & $0.67^{\text {ns }}$ \\
\hline AC x ST x TC & 6 & $15.64^{* *}$ & $0.79^{\text {ns }}$ & $0.36^{*}$ & $0.62^{\text {ns }}$ \\
\hline Error & 356 & 5.41 & 0.42 & 0.14 & 0.37 \\
\hline Coefficient of variation (\%) & & 79.61 & 24.09 & 25.43 & 51.10 \\
\hline General average & & 2.92 & 7.29 & 1.82 & 1.29 \\
\hline
\end{tabular}

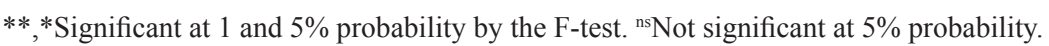

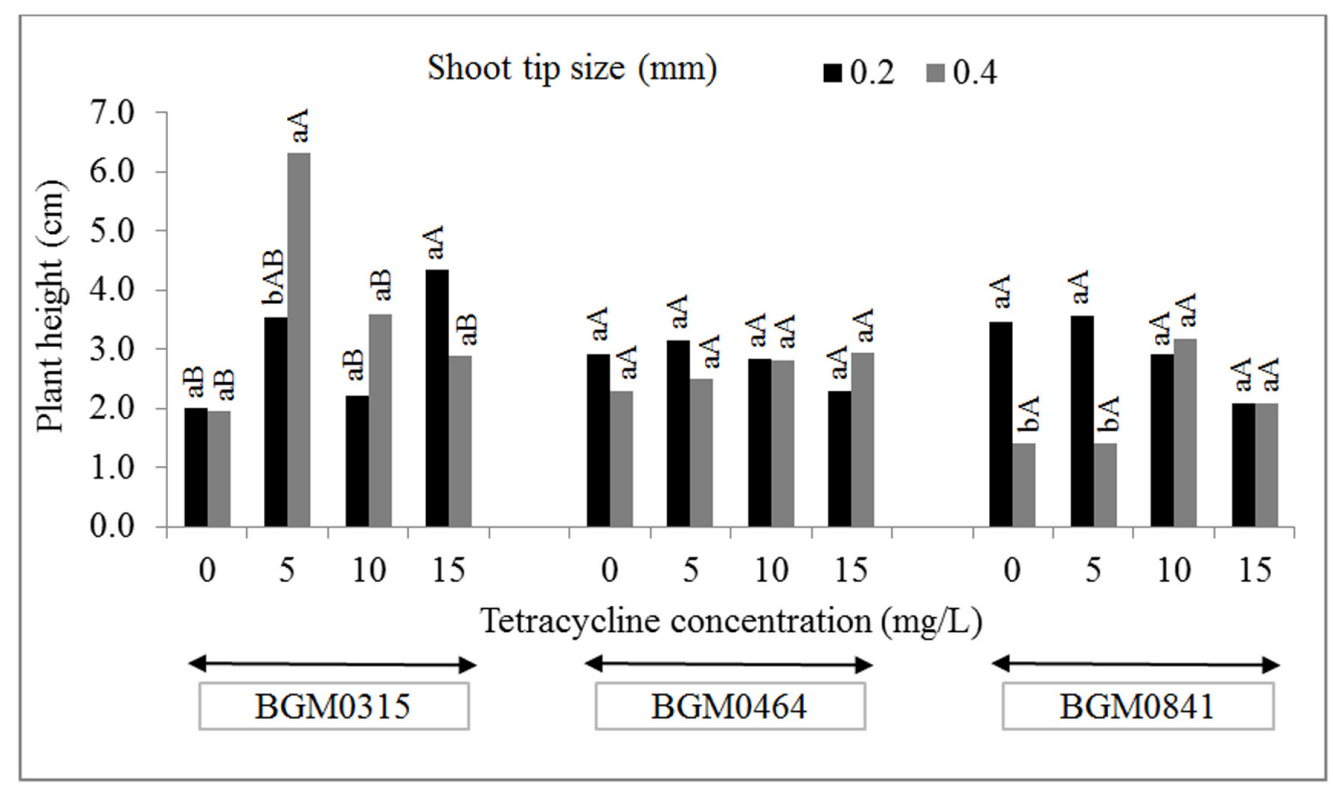

Figure 1. Average plant height values $(\mathrm{cm})$ of cassava from two shoot tip sizes of accessions BGM0315, BGM0464, and BGM0841 cultivated in vitro in tetracycline concentrations for 60 days, evaluated after 30 days of subculture. Means followed by the same lowercase letters do not differ by the F-test $(\mathrm{P}<0.05)$ by comparing apex size in each tetracycline concentration, while the same uppercase letters do not differ by the Tukey test $(\mathrm{P}<0.05)$, by comparing different concentrations of tetracycline in every apex size for each accession.

The PH assessment is considered important in pathogen cleanup activities because smaller shoots cannot survive during acclimatization, given that cassava is highly sensitive during this step, especially in light of the changes in temperature and relative humidity that occur during the acclimatization phase. In this context, BGM0315 plants from the 0.4-mm apexes, grown in medium containing $5 \mathrm{mg} / \mathrm{L}$ tetracycline, would be most likely to survive in the acclimatization phase. Moreover, larger plants are more suitable for micropropagation because they increase the proliferation rate and can accelerate the clonal propagation of free-frogskin materials.

Genetics and Molecular Research 16 (2): gmr16029556 
Other authors have reported an increased survival rate of cassava plants at a concentration of $10 \mathrm{mg} / \mathrm{L}$ ribavirin, compared with other treatments $(20$ and $30 \mathrm{mg} / \mathrm{L}$ ), and this concentration was also the most effective in eliminating CBSV (Mwangangi et al., 2014). Senula et al. (2000) also added ribavirin ( 50 or $100 \mathrm{mg} / \mathrm{L}$ ) in the culture medium and observed a reduction in plant regeneration and a significant increase in elimination of viruses in garlic (from 19.6 to $59.3 \%$ ). However, the concentration of $100 \mathrm{mg} / \mathrm{L}$ ribavirin caused deformation and hyperhydration in 90 to $100 \%$ of plants from larger explants $(1 \mathrm{~mm})$, making them unsuitable, while there was no regeneration in the smaller explants $(0.3 \mathrm{~mm})$.

For the NGL assessment, the highest averages were observed in BGM0464, with different behavior in relation to tetracycline concentrations (Figure 2). For the BGM0315 accession, the lower NGL was found at a concentration of $10 \mathrm{mg} / \mathrm{L}$, while for BGM0464 and BGM0841, the lowest NGL occurred in the absence of tetracycline, thereby indicating that the antibiotic was favorable to NGL development in these accessions (Figure 2). As the leaves are responsible for energy uptake and organic compound synthesis, more leaves will result in a higher fruit set rate in the acclimatization phase and therefore in the field.

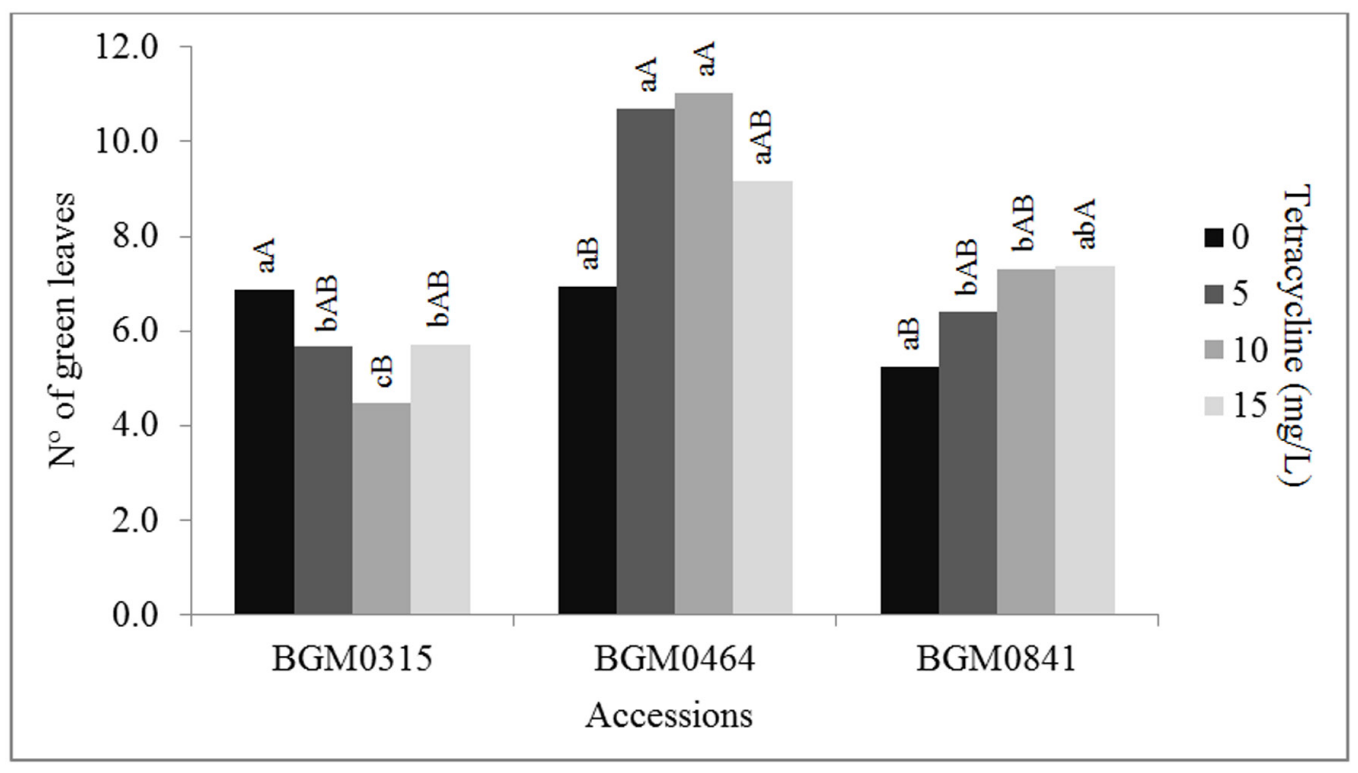

Figure 2. Average number of plant green leaves from two shoot tip sizes of accessions BGM0315, BGM0464, and BGM0841 cultivated in vitro in tetracycline concentrations for 60 days, 30 days after subcultivation. Means followed by the same letters do not differ by the Tukey test $(\mathrm{P}<0.05)$; lowercase letters compare accession at each tetracycline concentration while uppercase letters compare different tetracycline concentrations in each accession.

Regarding the apex size due to the tetracycline concentration, no significant differences were observed between the antibiotic concentrations in the NGL characteristic. Only a variation was observed between the two apex sizes at concentrations of 10 and $15 \mathrm{mg} / \mathrm{L}$, with higher amounts of live leaves present in the plants from 0.04-mm explants (Figure 3). Banerjee et al. (2010) suggested that the explants' size can significantly influence the survival rate and success of the culture clonal cleaning. Furthermore, they mentioned that among the three methods used for phytoplasma disposal (thermotherapy, tissue culture, and chemotherapy),

Genetics and Molecular Research 16 (2): gmr16029556 
the most widely used for the disposal of such pathogens is the culture of the apical meristem, which alone can promote systemic pathogen elimination because meristematic tissues are not vascularized. As an example, Milošević et al. (2011) had a cleaning efficiency at $80 \%$ of the meristems ( 0.3 to $1.5 \mathrm{~mm}$ ) of Impatiens hawkeri Bull. infected with the Tomato spotted wilt virus (TSWV). Then, Milošević et al. (2012) demonstrated 75\% cleaning efficiency in Impatiens walleriana plants infected with TSWV when using only meristem cultivation. Therefore, the above authors also reported that the effectiveness of viral cleaning depends on the genotype, and the risk of failing to clean also increases with the explant size.

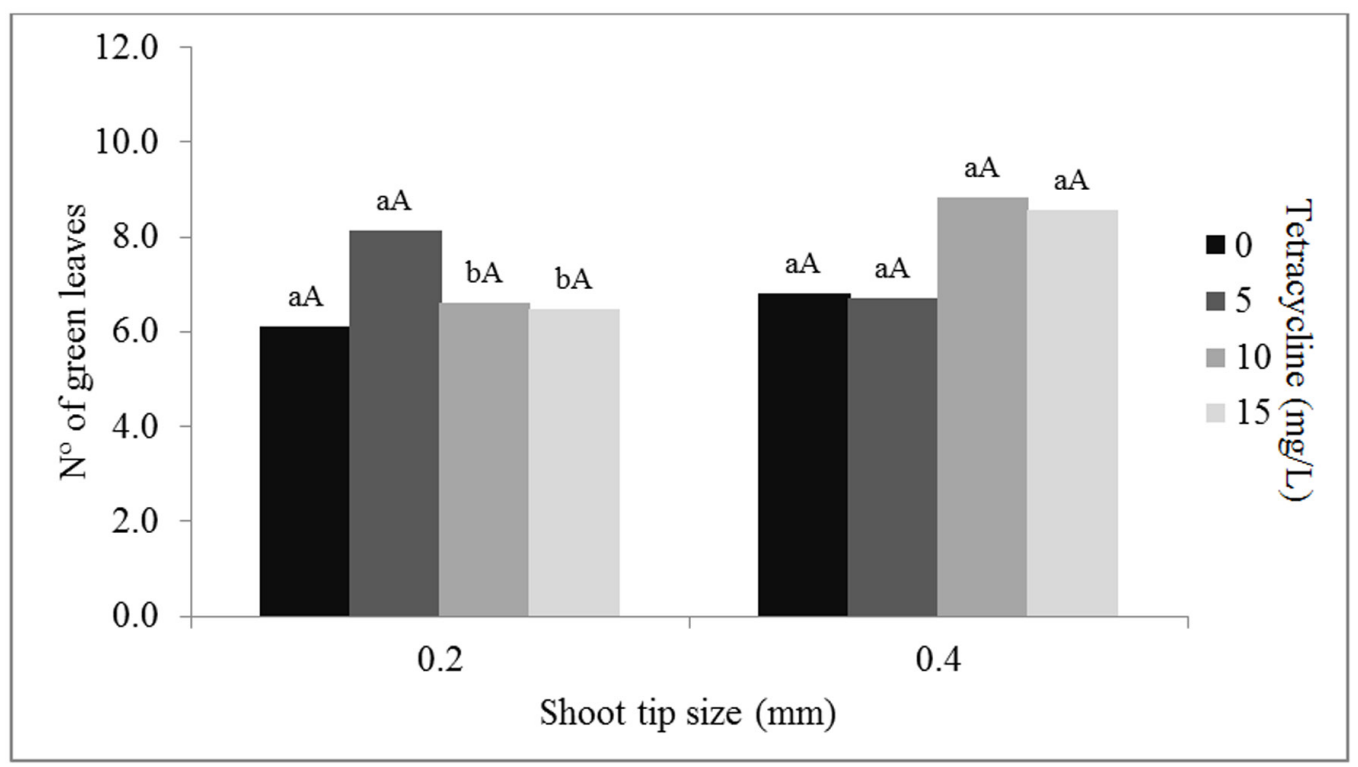

Figure 3. Average number of green leaves from two shoot tip sizes of accessions BGM0315, BGM0464, and BGM0841 cultivated in vitro in tetracycline concentrations for 60 days, 30 days after subcultivation. Means followed by the same lowercase letters do not differ by the F-test $(\mathrm{P}<0.05)$, by comparing apex size in each tetracycline concentration, while the same uppercase letters do not differ by the Tukey test $(\mathrm{P}<0.05)$, by comparing different tetracycline concentrations in each apex size.

Alam et al. (2013) successfully used meristems with sizes ranging from 0.3 to 0.5 $\mathrm{mm}$ in virus elimination, since they could not find surviving sweet potato plants when using meristems smaller than $0.3 \mathrm{~mm}$. Mwangangi et al. (2014) evaluated, among other factors, the effect of shoot tip sizes $(0.5,1,2$, and $10 \mathrm{~mm})$ in eliminating CBSV in cassava plants. As a result, the authors mention that $63 \%$ of the plants regenerated from established shoot tips of $0.5 \mathrm{~mm}$, compared to $88 \%$ of the $2-\mathrm{mm}$ shoot tips, underscoring that the greater the apex size the greater the number of regenerated plants, and the number of virus-free seedlings was inversely proportional to the explants' size.

In Senula et al.'s (2000) study, after culturing in vitro garlic meristematic apexes ( 0.3 to $0.8 \mathrm{~mm}$ ), the in vitro plant regeneration rate ranged from 1 to $80 \%$ depending on the genotype, and the viruses were eliminated in 85 to $95 \%$ of these plants. In the genotype, the survival of the explants was influenced by meristem size, since explants of approximately $1 \mathrm{~mm}$ showed

Genetics and Molecular Research 16 (2): gmr16029556 
90 to $100 \%$ regeneration, while smaller meristems (one leaf primordium) developed more slowly; there was no regeneration in six genotypes. In other studies, the virus elimination frequency by shoot tip cultivation decreased from 31 to $12 \%$ when the size of apexes increased from 0.3 to $1.5 \mathrm{~mm}$ (Yin et al., 2011). For Parmessur et al. (2002), meristematic apexes larger than $1 \mathrm{~mm}$ were more likely to remain infected, which did not occur in meristems smaller than $0.3 \mathrm{~mm}$. As not all meristem tips are virus free, Parmessur et al. (2002) emphasized the need for more sensitive diagnostic tools for indexing plants.

For the NR assessment, a significant difference was observed between accessions only at a concentration of $10 \mathrm{mg} / \mathrm{L}$ tetracycline, and the BGM0464 showed less NR (Figure 4). Such accession is probably more sensitive to tetracycline, given that the use of antibiotics can result in phytotoxicity inhibiting plant growth and development.

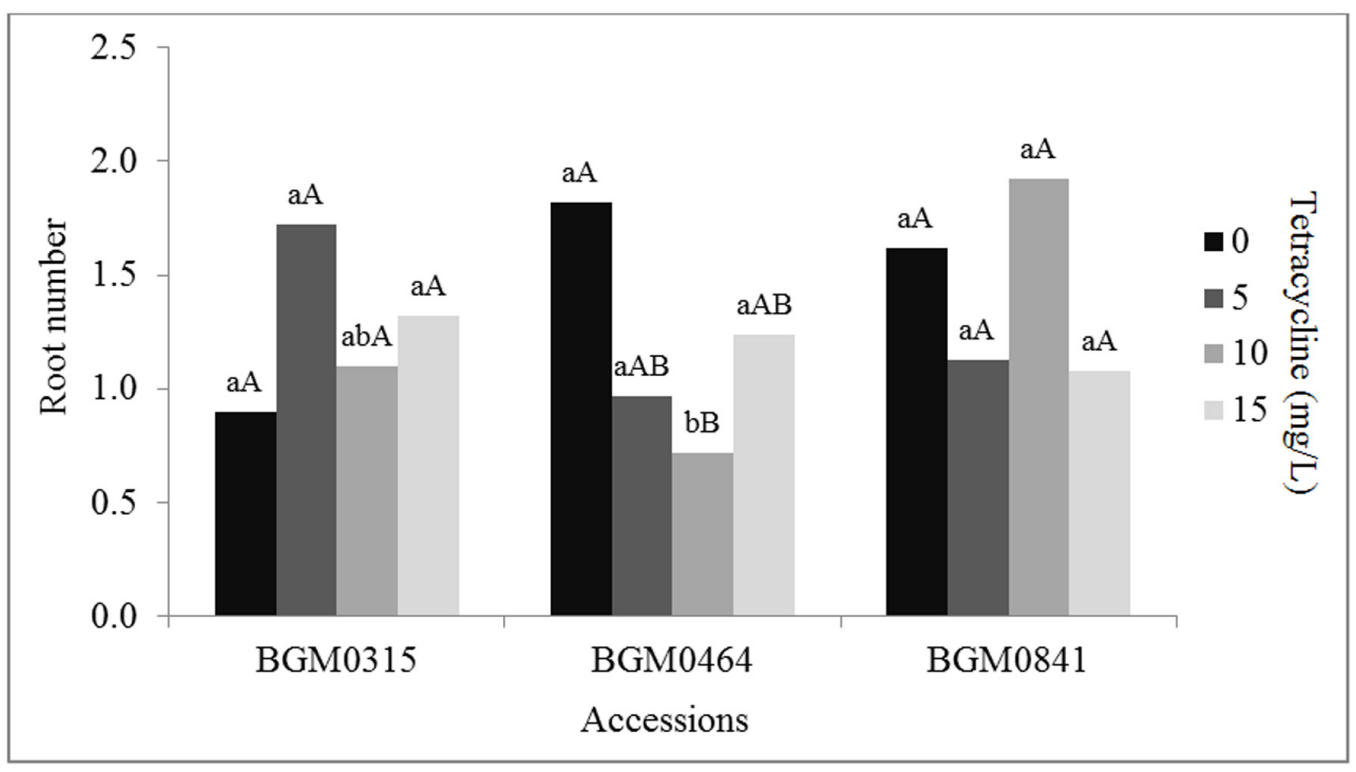

Figure 4. Average number of cassava roots from two shoot tip sizes of accessions BGM0315, BGM0464, and BGM0841 cultivated in vitro in tetracycline concentrations for 60 days, 30 days after subcultivation. Means followed by the same letters do not differ by the Tukey test $(\mathrm{P}<0.05)$; lowercase letters compare accessions at each tetracycline concentration and uppercase letters compare different tetracycline concentrations in each accession.

Considering the different cassava accessions due to the shoot tip size, there was no difference between accession and apex sizes for NR, except for BGM0841, which showed lower NR in $0.4 \mathrm{~mm}$ (Figure 5). This could be related to the fact that apexes with $0.2 \mathrm{~mm}$ are naturally free from pathogens. However, many studies have shown the presence of endophytic microorganisms in several species grown in vitro, and this interaction between plants and microorganisms can stimulate plant growth (Esposito-Polesi, 2011).

Regarding the NM, there is a variation between the apex sizes at a concentration of 10 $\mathrm{mg} / \mathrm{L}$ tetracycline for accession BGM0315 with lower NM in the $0.2 \mathrm{~mm}$. For BGM0464 and BGM0841, there was only a difference between apex sizes in the production of microcuttings

Genetics and Molecular Research 16 (2): gmr16029556 
at a concentration of $5 \mathrm{mg} / \mathrm{L}$, with higher $\mathrm{NM}$ at $0.2 \mathrm{~mm}$ (Figure 6). These results show an example of what happens to other cultures and the difference on morphogenetic responses among genotypes for some traits (Nogueira et al., 2001).

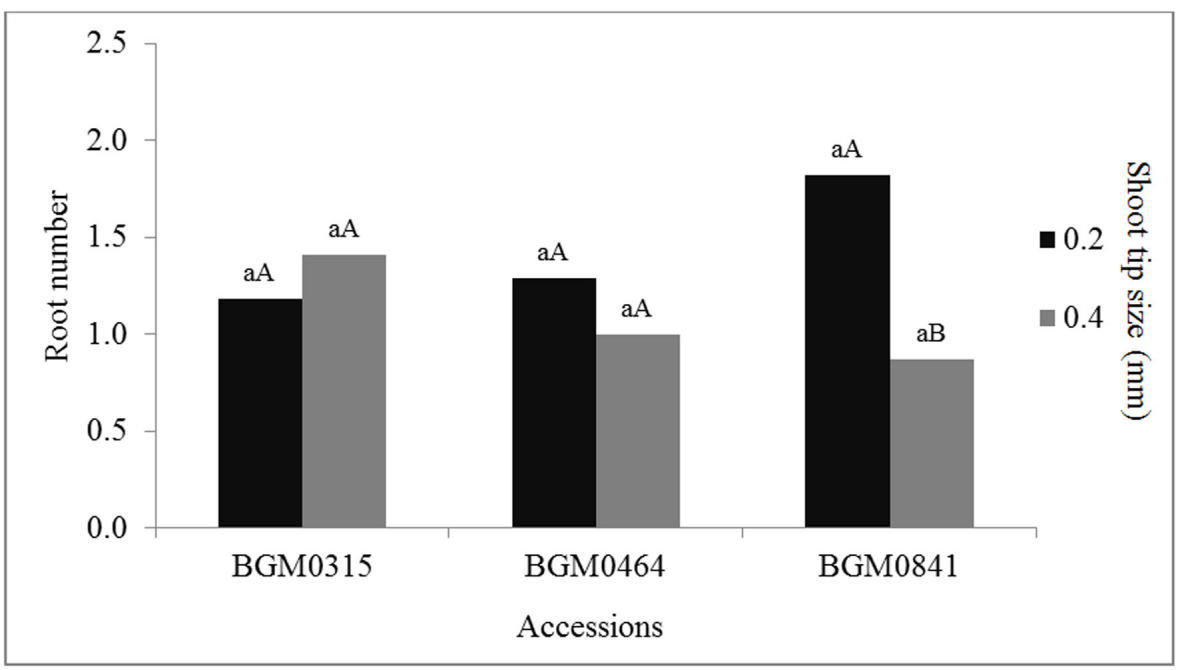

Figure 5. Average number of cassava roots from two shoot tip sizes of accessions BGM0315, BGM0464, and BGM0841 cultivated in vitro in tetracycline concentrations for 60 days, 30 days after subcultivation. Means followed by the same lowercase letters do not differ by the Tukey test $(\mathrm{P}<0.05)$, by comparing accessions in each apex size, while the same uppercase letters do not differ by the F-test $(\mathrm{P}<0.05)$, by comparing different apex size for each accession.

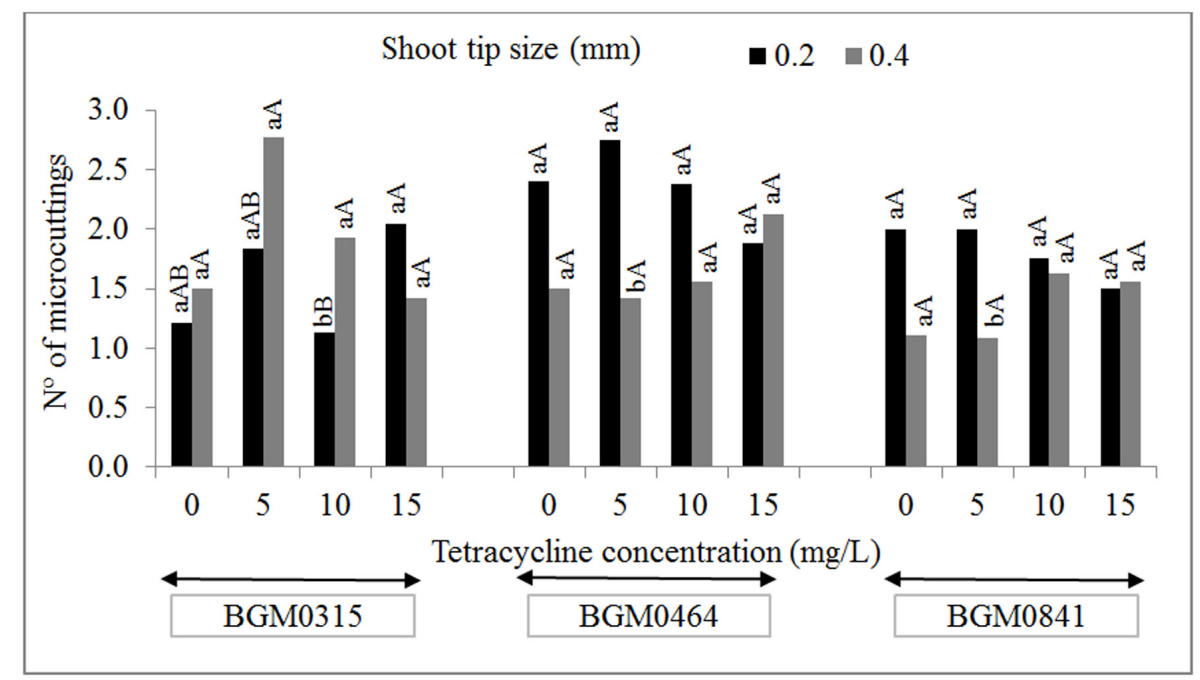

Figure 6. Average number of microcuttings from two shoot tip sizes of accessions BGM0315, BGM0464, and BGM0841 cultivated in vitro in tetracycline concentrations for 60 days, 30 days after subcultivation. Means followed by the same lowercase letters do not differ by the F-test $(\mathrm{P}<0.05)$ by comparing apex size in each tetracycline concentration, while the same uppercase letters do not differ by the Tukey test $(\mathrm{P}<0.05)$, by comparing different concentrations of tetracycline in every apex size for each accession.

Genetics and Molecular Research 16 (2): gmr16029556 
In general, we observed different behavior between the accessions used in this study regarding the in vitro cultivation of shoot tip in culture medium with tetracycline. The antibiotic concentrations used in the fourth trial did not affect the regenerative capacity of the explants. Furthermore, there were no major differences regarding shoot tip size in plant development, making it possible to identify some variations between treatments on the basis of antibiotic concentrations and the morphogenetic potential of the genotypes.

Positive and negative effects of the antibiotics in culture medium vary depending on the phytotoxicity as well as the species and type of plant material used. In potatoes, for example, Pereira and Fortes (2003) reported that ampicillin was the only antibiotic that did not affect the survival and development of shoots for the multiplication, even at the highest concentration $(1.024 \mathrm{~g} / \mathrm{L})$, and after a 21 -day culture, there was about $100 \%$ survival explants. Pereira and Fortes (2003) emphasized that the 1 antibiotics, chloramphenicol, streptomycin, and tetracycline, negatively affected the in vitro development of potato, causing a significant decrease in shoot height and multiplication rate along with the increase of their concentrations in the culture medium. Moreover, Ćurković-Perica and Ježić (2010) reported that in Catharanthus roseus (L.) G. Don, none of the quercetin concentrations $(10,100$, or $1 \mathrm{mM})$ showed efficient cleaning of plants infected with phytoplasma. Kamińska et al. (2005) also found that in roses the antibiotics baytril and gentamicin were phytotoxic at concentrations of 25 and $50 \mathrm{mg} / \mathrm{L}$, and, furthermore, have not been effective to eliminate phytoplasma.

\section{Symptomatic and molecular analyses of plants under field conditions to assess protocol efficiency}

The plants obtained from the CFSD cleaning treatments were planted in the field and were evaluated for the presence of disease symptoms at 7 months. After harvesting and visual analysis of the roots, it was proven that the efficiency of disease elimination in plants by the association of the tissue culture with thermotherapy and chemotherapy occurred, since for most treatments there was 100\% cleaning of infected plants (Table 2). However, the results showed that even without the presence of the tetracycline antibiotic in the culture medium during the in vitro culture phase, the plants from accessions BGM0315, BGM0464, and BGM0841 showed no symptoms of the disease in the roots. Thus, the in vitro 0.2 or $0.4 \mathrm{~mm}$ cultivation apexes were effective in eliminating CFSD in infected plants, even without the use of antibiotics in the culture medium.

In accession BGM0315, plants were identified with symptoms of CFSD in the root treatments $-0.2 \mathrm{~mm}$ apical grown in culture medium containing tetracycline $5 \mathrm{mg} / \mathrm{L}(10 \%$ of infected plants), shoot tip $0.4 \mathrm{~mm}$ without tetracycline (12.5\% of infected plants) - in the presence of $5 \mathrm{mg} / \mathrm{L}$ (20.0\% of infected plants) and $15 \mathrm{mg} / \mathrm{L}$ tetracycline $(12.5 \%$ of infected plants) (Table 2). These results suggest that for the BGM0315 genotype, the CFSD cleaning process is less efficient in comparison with other accessions, which may be related to morphogenetic differences between this genotype and the others, as well as the existence of a higher pathogenic on the shoot tips of this accession. In future studies, BGM0315 should be evaluated with higher concentrations of tetracycline or other antibiotics to verify cleaning efficiency.

Besides CFSD, we also verified the effectiveness of cleaning CsVMV in the accessions BGM0315 and BGM0464. From a total of 143 plants analyzed, only three $(2 \%)$ had fragments associated with CsVMV in PCR. Positive samples were taken from the treatments: BGM0315 - $0.4 \mathrm{~mm}$ shoot tip cultured in the tetracycline concentration at $5 \mathrm{mg} / \mathrm{L}$; and BGM0464 - 0.4

Genetics and Molecular Research 16 (2): gmr16029556 
$\mathrm{mm}$ shoot tip grown in tetracycline concentrations at 10 and $15 \mathrm{mg} / \mathrm{L}$. Therefore, the shoot tip of $0.2 \mathrm{~mm}$ was more efficient in eliminating CsVMV than the one of $0.4 \mathrm{~mm}$. The results show that the protocol used, besides being effective in eliminating the frogskin disease, was also efficient in eliminating the CsVMV. The efficiency of cleaning CsVMV was much higher than that reported in sweet potato culture for Sweet potato feathery mottle virus (SPFMV; Potyvirus) and Sweet potato mild mottle virus (SPMMV), as well as for complex infection in which approximately $85 \%$ of plants were cleaned with the use of meristem at 0.3 to $0.5 \mathrm{~mm}$ (Alam et al., 2013).

Table 2. Efficiency of cassava frogskin disease (CFSD) cleaning in in vitro shoot tip culture, after thermotherapy and tetracycline treatments, evaluated 7 months after cultivation in field conditions.

\begin{tabular}{|c|c|c|c|c|}
\hline Accession & Apex sizes $(\mathrm{mm})$ & Tetracycline concentrations $(\mathrm{mg} / \mathrm{L})$ & Total number of plants (field) & Plants with no CFSD root symptoms (\%) \\
\hline \multirow[t]{8}{*}{ BGM0315 } & \multirow[t]{4}{*}{0.2} & 0 & 9 & 100.0 \\
\hline & & 5 & 10 & 90.0 \\
\hline & & 10 & 8 & 100.0 \\
\hline & & 15 & 8 & 100.0 \\
\hline & \multirow[t]{4}{*}{0.4} & 0 & 8 & 87.5 \\
\hline & & 5 & 10 & 80.0 \\
\hline & & 10 & 8 & 100.0 \\
\hline & & 15 & 8 & 87.5 \\
\hline \multirow[t]{8}{*}{ BGM0464 } & \multirow[t]{4}{*}{0.2} & 0 & 10 & 100.0 \\
\hline & & 5 & 10 & 100.0 \\
\hline & & 10 & 10 & 100.0 \\
\hline & & 15 & 10 & 100.0 \\
\hline & \multirow[t]{4}{*}{0.4} & 0 & 5 & 100.0 \\
\hline & & 5 & 8 & 100.0 \\
\hline & & 10 & 10 & 100.0 \\
\hline & & 15 & 10 & 100.0 \\
\hline \multirow[t]{8}{*}{ BGM0841 } & \multirow[t]{4}{*}{0.2} & 0 & 10 & 100.0 \\
\hline & & 5 & 10 & 100.0 \\
\hline & & 10 & 10 & 100.0 \\
\hline & & 15 & 10 & 100.0 \\
\hline & \multirow[t]{4}{*}{0.4} & 0 & 8 & 100.0 \\
\hline & & 5 & 5 & 100.0 \\
\hline & & 10 & 10 & 100.0 \\
\hline & & 15 & 10 & 100.0 \\
\hline
\end{tabular}

Mwangangi et al. (2014) had 88.2, 72.0, and 66.7\% CBSV-free cassava plants from the $0.5-, 1.0-$, and $2.0-\mathrm{mm}$ meristem tips, respectively. These authors reported that higher percentages of virus-free plants were obtained due to the increased concentrations of ribavirin and salicylic acid antiviral substances. Furthermore, they found that thermotherapy treatment $\left(38^{\circ} \mathrm{C}\right)$ combined with the use of a $1-\mathrm{mm}$ shoot tip resulted in $68.8 \%$ of regenerated plants and $84.4 \%$ plant-free viruses.

Singh et al. (2007) submitted explants derived from shoot tip $(>0.5 \mathrm{~mm})$ of Catharanthus roseus L. (G.) Don infected with phytoplasma to different concentrations of oxytetracycline $(25,50,75$, and $100 \mathrm{mg} / \mathrm{L})$ for 2 weeks followed by six subcultures in medium without antibiotics. These authors reported that $50 \%$ of infected plants from explants and cultured in medium containing $75 \mathrm{mg} / \mathrm{L}$ oxytetracycline antibiotic were free of phytoplasma and remained after 3 years.

The CFSD cleaning efficiency was only analyzed based on the symptoms under field conditions, whereas the molecular diagnosis currently available for indexing has shown inconsistent results in cassava accessions known to be infected based on visual analysis of field 
symptoms. On the other hand, some authors have shown success in molecular diagnosis of phytoplasmas, such as Gribaudo et al.'s (2007) sample in plant matrices and micropropagated vines using nested-PCR and RFLP with 100\% cleaning efficiency in vitro culture of axillary buds in culture medium with oxytetracycline.

Mwangangi et al. (2014) used RT-PCR to confirm the deletion of the CBSV in infected cassava plants, and the analysis showed that thermotherapy $\left(38^{\circ} \mathrm{C}\right)$ in combination with the apex meristem cultivation resulted in $84 \%$ of the virus-free plants. The PCR technique has also been used for molecular diagnosis of African cassava mosaic virus (ACMV) and East African cassava mosaic virus (EACMV) in cassava (Nkaa et al., 2013).

Despite the aspects and techniques covered in other studies, Alam et al. (2013) mentioned that serological methods or other molecular diagnostics impact on cost-effectiveness analysis. Therefore, these authors also evaluated the efficiency of clonal cleaning from the visual analysis of the virus symptoms in sweet potato plants from meristem culture grafted indicator plants. Although it was not possible to perform molecular diagnoses, and thus using only visual data symptoms present in 7-month growth plants, this study presents important results for the supply of healthy propagation material, maintaining the sustainability and competitiveness of the cassava agribusiness. According to Fox (1997), no pathogens or disease identification method is comparable in reliability and simplicity; therefore, different diagnosis methods for plant diseases are often used in a complementary manner and not as an alternative.

\section{CONCLUSIONS}

Tetracycline at concentrations of 5 to $15 \mathrm{mg} / \mathrm{L}$ does not adversely affect the regeneration capacity of explants, being favorable to plant growth in vitro for most treatments. Cassava explants subjected to in vitro culture associated with thermotherapy and chemotherapy are effective in viral cleaning of CsVMV and CFSD.

\section{Conflicts of interest}

The authors declare no conflict of interest.

\section{ACKNOWLEDGMENTS}

The authors thank FAPESB, CAPES, and CNPq for the financial assistance and scholarship support.

\section{REFERENCES}

Alam I, Sharmin SA, Naher MK, Alam MJ, et al. (2013). Elimination and detection of viruses in meristem-derived plantlets of sweetpotato as a low-cost option toward commercialization. 3 Biotech $3: 153-164$. https://doi.org/10.1007/s13205$\underline{012-0080-6}$

Ali MA, Nasiruddin KM, Haque MS and Faisal SM (2013). Virus elimination in potato through meristem culture followed by thermotherapy. SAARC J. Agric. 11: 71-80.

Alvarez E, Mejía JF, Llano GA, Loke JB, et al. (2009). Characterization of a phytoplasma associated with frogskin disease in cassava. Plant Dis. 93: 1139-1145. https://doi.org/10.1094/PDIS-93-11-1139

Banerjee S, Haider F, Bagchi GD and Samad A (2010). Regeneration of phytoplasma-free Artemisia roxburghiana Besser var. purpurascens (Jacq.) Hook. plants using apical meristem culture. Plant Cell Tiss. Org 103: 189-196.

Genetics and Molecular Research 16 (2): gmr16029556 
Calvert LA and Thresh JM (2002). Cassava: biology, production and utilization. In: The viruses and virus diseases of cassava (Hillocks RJ, Thresh JM and Belloti A, eds.). CABI Publishing, Wallingford, 237-260.

Calvert LA, Ospina MD and Shepherd RJ (1995). Characterization of cassava vein mosaic virus: a distinct plant pararetrovirus. J. Gen. Virol. 76: 1271-1278. https://doi.org/10.1099/0022-1317-76-5-1271

Carvajal-Yepes M, Olaya C, Lozano I, Cuervo M, et al. (2014). Unraveling complex viral infections in cassava (Manihot esculenta Crantz) from Colombia. Virus Res. 186: 76-86. https://doi.org/10.1016/j.virusres.2013.12.011

Chalak L, Elbitar A, Rizk R, Choueiri E, et al. (2005). Attempts to eliminate 'Candidatus phytoplasma phoenicum' from infected Lebanese almond varieties by tissue culture techniques combined or not with thermotherapy. Eur. J. Plant Pathol. 112: 85-89. https://doi.org/10.1007/s10658-004-7953-4

Ćurković-Perica M and Ježić M (2010). Detrimental effect of quercetin on phytoplasma infected Catharanthus roseus (L.) G. Don shoots grown in vitro. Acta Bot. Croat. 69: 155-162.

Doyle JJ and Doyle JL (1987). A rapid DNA isolation procedure for small amounts of fresh leaf tissue. Phytochem. Bull. 19: 11-15.

Esposito-Polesi NP (2011). Microrganismos endofíticos e a cultura de tecidos vegetais: quebrando paradigmas. Rev. Bras. Biocienc. 9: 533-541.

Foloni JSS, Tiritan CS and Santos DH (2010). Avaliação de Cultivares de Mandioca na Região Oeste do Estado de São Paulo. Agrarian (Dourados) 3: 44-50.

Fox RTV (1997). The present and future use of technology to detect plant pathogens to guide disease control in sustainable farming systems. Agric. Ecosyst. Environ. 64: 125-132. https://doi.org/10.1016/S0167-8809(97)00030-3

Gribaudo I, Ruffa P, Cuozzo D, Gambino G, et al. (2007). Attempts to eliminate phytoplasmas from grapevine clones by tissue culture techniques. B. Insectol 60: 315-316.

Kamińska M, Podwyszyńska M and Śliwa H (2005). Phytoplasma detection in rose shoots propagated in vitro. Acta Soc. Bot. Pol. 74: 181-186. https://doi.org/10.5586/asbp.2005.023

Lenis JI, Calle F, Jaramillo G, Pérez JC, et al. (2006). Leaf retention and cassava productivity. Field Crops Res. 95: 126134. https://doi.org/10.1016/j.fcr.2005.02.007

López CE, Restrepo S and Verdier V (2006). Limitations of cassava bacterial blight: New advances. Acta Biol. Colomb. 11: 21-45.

Mattos PLP, Souza AS and Ferreira Filho JR (2006). Aspectos socioeconômicos e agronômicos da mandioca. In: Propagação (Souza LS, Farias ARN, Mattos PLP and Fukuda WMG, eds.). Embrapa Mandioca e Fruticultura Tropical, Cruz das Almas, 455-491.

Menezes Júnior FOG (2011). Cultivo in vitro de alho visando a limpeza clonal. Rev. Ciênc. Agrovet. 10: 158-167.

Milošević S, Subotić A, Bulajić A, Djekić I, et al. (2011). Elimination of TSWV from Impatiens hawkerii Bull. and regeneration of virus-free plant. Electron. J. Biotechnol. 14: 1-10.

Milošević S, Cingel A, Jevremović S, Stanković I, et al. (2012). Virus elimination from ornamental plants using in vitro culture techniques. Pestic. Fitomed. 27: 203-211. https://doi.org/10.2298/PIF1203203M

Mowat WP and Dawson S (1987). Detection and identification of plant viruses by ELISA using crude sap extracts and unfractionated antisera. J. Virol. Methods 15: 233-247. https://doi.org/10.1016/0166-0934(87)90101-7

Murashige T and Skoog F (1962). A revised medium for rapid growth and bioassays with tobacco tissue culture. Physiol. Plant. 15: 473-497. https://doi.org/10.1111/j.1399-3054.1962.tb08052.x

Mwangangi M, Ateka E, Nyende A and Kagundu A (2014). Elimination of cassava brown streak virus from infected cassava. J. Biol. Agric. Healthc 4: 34-40.

Nascimento LC, Pio-Ribeiro G, Willadino L and Andrade GP (2003). Stock indexing and potato virus y elimination from potato plants cultivated in vitro. Sci. Agr 60: 525-530. https://doi.org/10.1590/S0103-90162003000300017

Nkaa FA, Ene-Obong EE, Taylor N, Fauquet C, et al. (2013). Elimination of African Cassava Mosaic Virus (ACMV) and East African Cassava Mosaic Virus (EACMV) from cassava (Manihot esculenta Crantz) cv. 'Nwugo' via somatic embryogenesis. Am. J. Biotech. Mol. Sci. 3: 33-40.

Nogueira FTS, Costa MG, Figueira ML, Otoni WC, et al. (2001). Regeneração in vitro de plantas de tomateiros 'Santa Clara' e seu mutante natural 'Firme'. Cienc. Agrotec. 25: 63-71.

Oliveira EJ, Santana FA, Oliveira LA and Santos VS (2015). Genotypic variation of traits related to quality of cassava roots using affinity propagation algorithm. Sci. Agr 72: 53-61. https://doi.org/10.1590/0103-9016-2014-0043

Oliveira SAS, Abreu EFM, Araújo TS, Oliveira EJ, et al. (2014). First report of a 16srIII-L phytoplasma associated with frogskin disease in cassava (Manihot esculenta Crantz) in Brazil. Plant Dis. 98: 153-153. https://doi.org/10.1094/ PDIS-05-13-0499-PDN

Panattoni A, D'Anna F, Cristani C and Triolo E (2007). Grapevine vitivirus A eradication in Vitis vinifera explants by antiviral drugs and thermotherapy. J. Virol. Methods 146: 129-135. https://doi.org/10.1016/j.jviromet.2007.06.008

Genetics and Molecular Research 16 (2): gmr16029556 
Panattoni A, Luvisi A and Triolo E (2013). Review: elimination of viruses in plants: twenty years of progress. Span. J. Agric. Res. 11: 173-188. https://doi.org/10.5424/sjar/2013111-3201

Parmessur Y, Aljanabi S, Saumtally S and Dookun-Saumtally A (2002). Sugarcane yellow leaf virus and sugarcane yellows phytoplasma: elimination by tissue culture. Plant Pathol. 51: 561-566. https://doi.org/10.1046/j.13653059.2002.00747.x

Pereira JES and Fortes GRL (2003). Toxicidade de antibióticos no cultivo in vitro da batata em meios semi-sólido e líquido. Pesqui. Agropecu. Bras. 38: 1273-1279. https://doi.org/10.1590/S0100-204X2003001100004

Senula A, Keller ERJ and Lesemann DE (2000). Elimination of viruses through meristem culture and thermotherapy for the establishment of an in vitro collection of garlic (Allium sativum). Acta Hortic. 530: 121-128. https://doi. org/10.17660/ActaHortic.2000.530.12

Singh SK, Aminuddin SP, Singh BR and Khan JA (2007). Production of phytoplasma-free plants from yellow leaf diseased Catharanthus roseus L. (G.) Don. J. Plant Dis. Prot. 114: 2-5. https://doi.org/10.1007/BF03356195

Souza AN, Silva F, Bedendo IP and Carvalho CM (2014). A phytoplasma belonging to a 16SrIII-A subgroup and dsRNA virus associated with cassava frogskin disease in Brazil. Plant Dis. 98: 771-779. https://doi.org/10.1094/PDIS-0413-0440-RE

Venturini MT, Santos VS and Oliveira EJ (2015). Procedures for evaluating the tolerance of cassava genotypes to postharvest physiological deterioration. Pesqui. Agropecu. Bras. 50: 562-570. https://doi.org/10.1590/S0100204X2015000700006

Wang Q and Valkonen JPT (2008). Efficient elimination of sweet potato little leaf phytoplasma from sweetpotato by cryotherapy of in vitro grown shoot tips. Plant Pathol. 57: 338-347. https://doi.org/10.1111/j.1365-3059.2007.01710.x

Yin Z, Feng C, Wang Q, Engelmann F, et al. (2011). Cryotherapy of shoot tips: a newly emerging technique for efficient elimination of plant pathogens. Acta Hortic. 908: 373-384. https://doi.org/10.17660/ActaHortic.2011.908.49

Genetics and Molecular Research 16 (2): gmr16029556 